\title{
A rendőrtisztképzés és a tiszti továbbképzés reformja ${ }^{1}$
}

\section{KRATOCHWILL Ferenc ${ }^{2}$}

Kratochwill fơiigazgató úr életútjához szorosan kötődik a miskolci jogi kar alapítása, valamint a Rendőrtiszti Főiskola nagyívű reformja. Komoly vesztesége a rendészeti felsőoktatásnak, hogy ez utóbbi félbemaradt. A Rendészeti Szemle szerkesztősége kötelességének érzi, hogy a főigazgató úr szellemi végrendeletének tekinthető gondolatait - posztumusz - közzétegye.

A rendőrtisztképzés mennyisége és tartalma elsősorban attól függ, hogy milyen állásfoglalás alakul ki a magyar rendőrség tiszti létszámáról. Amennyiben a tiszti létszám aránya a jelenlegi 34, 6\% körül marad, a képzést a jelenlegi keretek között, de korszerűsített tartalommal kell folytatni. Ha az európai normáknak megfelelő 5-10\%-os arányra kívánjuk csökkenteni a tiszti beosztások számát, az ezredfordulótól kezdve a tisztképzést mintegy 1/3-ra kell csökkenteni és tartalmában is teljesen új alapokra kell helyezni (a minőségi kiválasztás erősítése, a képzés színvonalának emelése, a vezetési ismeretek előtérbe állítása stb.). Állást kell foglalni abban is, hogy a kétéves tiszthelyettesképzés és a főiskolai képzés között lesz-e külön nyomozóképzés, vagy a nyomozók alapképzése továbbra is a föiskola feladata marad.

\section{Tisztképzés a Rendőrtiszti Főiskolán}

A Rendőrtiszti Főiskolán (RTF) az ezredfordulót követően általános rendőrtisztképzést kell folytatni, de az átmeneti időszakban a képzési idő mintegy 1/3-ában lehetővé kell tenni a hallgatók szakosodását (bűnügyi, közrendvédelmi, közlekedési és igazgatásrendészeti szak).

Az RTF-re külső és belső pályázókat egyaránt fel kell venni. Ezen belül a felvehető külső és belső pályázók arányát az igényekre figyelemmel (Országos Rendőrfőkapitányság) tanévenként előre rögzíteni kell.

A külső pályázók szakmai képzetlenségére figyelemmel a szintrehozó alapképzés rendszerét (a jelenlegi „0.” évfolyam) fenn kell tartani, de a képzés tartalmi elemeit jobban hozzá kell igazítani a főiskolai képzéshez.

Kratochwill Ferenc: A rendőrtisztképzés és a tiszti továbbképzés reformja. Rendészeti Szemle, 31. (1993), 11. 5961. (másodközlés, dr. Dános Valér ny. r. vezérőrnagy egyetemi magántanár a Belügyi Szemle tudományos folyóirat főszerkesztőjének írásbeli hozzájárulásával).

2 Dr. Kratochwill Ferenc büntetőeljárás-jogász egyetemi tanár, a Miskolci Egyetem Állam- és Jogtudományi Karának alapítója, első dékánja, az ELTE Büntető Eljárásjogi Tanszékének vezetője, 1990-tôl haláláig a Rendőrtiszti Főiskola főigazgatója volt. 
A kétéves tiszthelyettesképzésre figyelemmel dönteni kell arról, hogy az ott végzettek milyen arányban és milyen formában kapcsolódhatnak be a főiskolai képzésbe. Erre figyelemmel kell dönteni a levelező tagozat sorsáról.

Mintegy 2-3 éven belül mind a nappali, mind a levelező tagozaton ki kell alakítani a főiskolai felvétel komplex rendszerét, amely

- a középiskolai képzés ismeretanyagához igazodó intelligenciamérés,

- az általános egészségügyi alkalmasság,

- a fizikai, kondicionális állapot és a terhelhetőség szintjének felméréséből áll.

Fokozni kell a képzés gyakorlati jellegét. Ennek érdekében legkésőbb 3-5 éven belül a képzési idő mintegy harmadát (nagyrészt a területi szerveknél folyó) gyakorlati képzéssé kell átalakítani.

A jelenlegi vizsgaközponti számonkérési rendszert differenciált, a gyakorlati munkát is értékelő minősítési rendszerré kell átalakítani. Az ezredfordulóig be kell vezetni, hogy a diploma megszerzésének feltétele legyen egy középfokú nyelvvizsga megszerzése.

Olyan képzési rendszert kell kialakítani, amelyben a hallgatók teljes tanulmányi idejük alatt a főiskola hallgatói állományába tartoznak, és a végzés után a beosztási helyek nagyobb részét pályázati úton töltik be.

Ki kell alakítani a hallgatói jogviszonyt (hallgatói státusz).

\section{A tiszti továbbképzés}

Az RTF-en tiszti vezetői továbbképzést (posztgraduális képzést) kell szervezni. A továbbképzés tartalmát tekintve nem lehet a főiskolán tanultak megismétlése, és nem követheti a jogászképzés modelljét. A képzés tartalmában rendőrségi ismeretigényekre épülő gyakorlatias vezetőképzés, amely a főkapitányi, kapitányi, esetleg osztályvezetői beosztások betöltéséhez szükséges ismeretekre terjed ki. Ezek szervezési és vezetési ismeretek, gazdálkodási ismeretek, informatikai, szociológiai, politológiai, kiegészítő idegen nyelvi képzés stb. A továbbképzés keretében gondoskodni kell az egyes rendőri szakterületek (például idegenrendészet, a gazdasági bünözés új vonásai, a nemzetközi szervezett bűnözés és a kábítószer-bűnözés elleni harc) ismeretanyagának elmélyítéséről.

A vezetőképzést a közeli jövőben rövidebb időtartamú tanfolyami formában, majd mintegy 4-5 év múlva egyéves nappali vagy kétéves levelező formában kell megszervezni. A képzéshez változó munkahelyeken folytatott képzés is tartozik.

A tiszti továbbképzésbe - az anyagi lehetőségektől függően - 2-3 hetes, más országok rendőrségein folytatott tájékozódást is be kell iktatni. 


\section{Az oktatási intézmények elvi irányítása}

Az oktatási reform elengedhetetlen feltétele, hogy a jövőben egyre jobban egymásra épülő iskolai és tanfolyami képzési rendszer egységes irányítás alá kerüljön, valamint összekapcsolódjék a kutatóhelyek tevékenységével is. Ennek érdekében a Belügyminisztérium vagy az Országos Rendőr-főkapitányság mellett, (esetleg közösen) a rendőrképzés összehangolására Oktatási Tanácsot (Kuratóriumot, Kollégiumot) kell szervezni.

A Tanácsnak véleményezési, egyes kérdésekben döntési jogokat kell biztosítani. Így a Tanács véleményezné (vagy átruházott jogkörben jóváhagyná) a képzési követelményeket, a tanterveket, a vezetői és a vezetői oktatói állások betöltését stb. A Tanács jogkörétől függően a belügyminiszternek, illetve az ORFK vezetőjének tesz javaslatot.

A Tanács elnöke a belügyminiszter által kijelölt személy. A Tanács titkára az ORFK erre a beosztásra kijelölt munkatársa, és az ORFK gondoskodik a Tanács múködtetéséről is. A Tanács tagjai: az iskolák vezetői és az országos rendőrfőkapitány által kijelölt személyek. 